\title{
Development Process and Its Implication on the Native Land Ownership
}

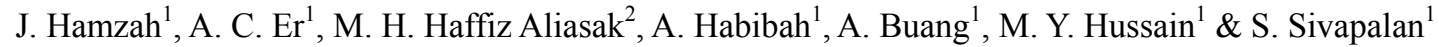 \\ ${ }^{1}$ School of Social, Development and Environment, Faculty of Social Science and Humanities, Universiti \\ Kebangsaan Malaysia, Bangi, Malaysia \\ ${ }^{2}$ Department of Estate Management, Faculty of Architecture, Planning and Surveying, Universiti Teknologi \\ Mara, Bandar Seri Iskandar, Malaysia \\ Correspondence: Hamzah Jusoh, School of Social, Development and Environmental Studies, Faculty of Social \\ Sciences and Humanities, Universiti Kebangsaan Malaysia, Bangi, Malaysia. E-mail: hj@ukm.my
}

Received: July 22, 2013 Accepted: September 1, 2013 Online Published: October 11, 2013

doi:10.5539/ass.v9n14p18 URL: http://dx.doi.org/10.5539/ass.v9n14p18

\begin{abstract}
Development process is a part of government and policy makers' agenda to introduce and implement the policies in order to create wealth creation as well as to improve livelihood in both rural and urban areas. To avoid over-concentration of development in urban areas, new development schemes for rural area development are also ventured. As a result of this scheme, two strategies to occupy rural land often utilized by the capitalist ventures in collaboration with the private developers are the land purchasing from the native land owners and the land acquisition from the state authorities. The resulting effect of these actions has been the changing pattern in terms of land ownership to the land losing phenomenon. The aim of this article is to analyse the pattern and the mechanism underlying the lost of the Malay land ownership in the District of Larut, Matang and Selama, Perak from year 2000 to 2008 as a consequent of development process. Utilizing the data collected from Department of Valuation and Property Services, Malaysia, land transaction were recorded. The results of the aggregate land transaction between Malay seller vs non-Malay buyer and non-Malay seller vs. Malay buyer still show the huge differences in number of land transactions and land sizes. While there were 179 pieces with an equivalent to 204.79 hectares of land not returned to the Malay owners, however, the land transaction between the Malays vs. non-Malay buyer also decrease. Two major factors have been identified as the impetus of such undertaking, i) a rise of awareness of the Northern economic Northern Corridor Economic Region impact on rural areas and ii) the rise of awareness of land ownership as a source of supremacy. It is imperative more awareness programmes on the importance of land ownership and generating wealth commercially be given to the rural community to ensure the native land supremacy in the future.
\end{abstract}

Keywords: Malay land ownership, land development, native land owner, land acquisition

\section{Introduction}

Land is an important asset for economic development utilized by varying actors ranging from an individual to the larger organization and government agencies. Without land, not only economic development activities and programs hardly been implemented, it can adversely impact on the community's livelihood, land rights and wealth creation. The main issues related to land however, are their rights and ownership to facilitate productive activities. In contemporary era, the Malay land ownership pattern has been seen reducing because of the lack of human ability to protect their right towards the land ownership, neglect of government policies' implementation and the owners themselves.

Ideally, land owned by the Malays should have increased over time, and the Malays should not only depend on the land gazette under existing laws such as the Malay Reservation Enactment, Land Development schemes implemented by the FELDA, FELCRA and the Bumiputra's quota for assets ownership including land under the New Economic Policy (NEP 1970-1990) (Ramaswamy, 2000; Harun, 2006; Hussain,1996; Nik Abdul Rashid, 1993). The National Development Plans provide direct support to this enhancement. However, the tendency of the Malays to dispose their land for development purposes was after they were offered a favorable price from the property developers, mostly from the non-Malays, is one of the main issues where the Malays lose their land. Simply, there exists a drastic 'land reduction' in the land bank of the rural areas. This scenario is also a pressing 
issue in some countries such as the United States of America, Canada, the Federation of Australia, New Zealand, South Africa and Singapore, where the native became minority communities and the immigrants dominated the country in terms of capital or assets (Shal, 2003; Frankema, 2006).

The existing literature assert on the four critical issues related to the Malay land ownership in Malaysia; namely the seize of the land by the moneylenders, land acquisition, dispute of the inheritance lands and voluntary disposal of land. Firstly, most of the Malay peasants cultivate their land with paddy and local fruits as their economic activities since decades. During the British Colonization period, the Malay peasants had never been encouraged to improve their socio-economic standing through capital support and training (Voon, 1976; Ibrahim, 1983; Ahmad, 2010; Buang, 2004; Amino \& Suyub, 2008). To obtain an initial capital, most of the Malay peasants find convenient approach such as borrowing capital from the Moneylenders specifically the Ceti (the Indian Moneylenders known as Chettiar). The Ceti provides loan for those who need capital to carry out his cultivation. They also provide the terms and conditions to the borrowers such as installment methods, interest rates, pledge and taking possession of the ownership of land if the borrower fails to make installment payments. Nowadays, the financial aids to the rural peasants including the Malays are still maintained.

Secondly, the land acquisition is used by the State Government to possess land from the registered owner as permitted under the Land Acquisition Act 1960 and Article 13, the Federal Constitutions of Malaysia (Buang, 1993; Ridzuan, 1994; Buang, 2003, 2007; Laws of Malaysia 2007a, 2007b, 2009). In this case, the state government will use the provisions under Section 3 of the Act to take the land known as eminent domain under circumstances of public purposes and national economy. This phenomenon is obvious to Malay lands located in the strategic areas or within town centres. When the land was taken by the government, the registered owner will receive the compensation in the form of money or housing lots or flats to replace the land and dwelling. This undertaking was apparent in several hot spot development areas in Peninsular Malaysia, including Langkawi, Ipoh, Johor Baru and Pulau Redang (Hadi, 1996). Even after the project completion, the Malays were unable to purchase the real property units as a result of inadequate capital and financial source.

Thirdly, family dispute over land is a common issue in the Malay community who inherited the property from previous owners who later died, leaving behind their property to their next-of-kin (Nik Mohd Zain, 1993; Ahmad, 1996; Buang, 2004; Means, 1972). Added to this is the fragmentation of land, especially when the land size is small, yet many parties have made their claim on the endowment of the property. As a result, not only the transfer made from first generation to second generation is an issue, a more pertinent issue is that the land is an uneconomical due to fragmentation of land.

Under the National Land Code 1965, land areas less than one acre is not permitted to be partitioned but multiple unit shares of land in one title is permitted (Abdullah, 1985; Abdullah 1997). When the land loses its economic values, an alternative often the unit shareholders of inherited lands choose is to dispose to those willing to buy at reasonable prices. When the land is sold, the nominees share the money among them. This transaction, however, it is not an issue when the land is sold to Malay. On the other hand, it was a issue when the land is sold to non-Malays as this will result a reduction of Malay reserve land.

The pressing issue is a voluntary disposal of land. This occurrence normally becomes apparent in the Malay land or Malay Reserved Land located in strategic areas; especially in towns, city centres or new development areas, which saw an attractive price transaction (Buang, 2003, 2007; Hussain, 1996). In these cases, the property developer bought the land from the Malay owners. This scenario also replicates in rural areas where the Malay land is dominant, and most important, these lands provide favourable economic development. Some of these areas are the FELDA Sg. Buaya, FELDA LB Johnson, and selective areas in Pahang and Negeri Sembilan. In such cases, the owners were found to willingly transferred his/her land to buyers who offered the best and highest price without taking into consideration the implication to the future generation. The effect of the Malay owners' action is that they may need to find other dwelling or return to their hometown and start their life in new area. Against this backdrop, this article aims to analyze the pattern of land loss in the state of Perak, with special emphasis on the transactions undertaken by the land owners.

\section{Literature Reviews}

There are copies of literature discussing on the pattern of land transactions and land loss in developing countries. While generally these phenomena were due to the economic factors, several authors claim that the multi-facet of development processes taking place in and within the areas are the impetus of various land transactions. Deny (1998) asserts on the implementation of development projects determinant of the losing of native land ownership through land transaction. Mukupa (2011) however, stressed that an incremental rise of land market in rural areas was a positive development consequences. 
Both Frankema (2006) and Shal (2003) agree that, due to the existence of monopoly among the influenced capitalists in the land development and commercial agricultural sector, the native community had less opportunities in sharing the economy benefits and profits. They even preferred to deal through voluntary or compulsory purchases. Anderson (1999) found that the land supply also determine land development. More pertinent, the lesser the land stock in urban areas, the faster the deals made in seeking new potential land in rural areas by the capitalists. Introducing a concept of "land hunger", Ratna (2001) stressed on the capitalists' land acquisition for economy and commercial developments purposes. Asiah et al. (2006) specifically define the concept of "land hunger" focusing on the scarcity of land for development purposes. Wakhungu et al. (2008) on another hand, expand the land scarcity for development projects is due to the stakeholders - the capitalists, developers and investors.

Taking an insight from the native community's perspective, land matters are now becoming pertinent. The native communities in the Peninsular Malaysia are the Malays and the Orang Asli ethnics (Sullivan, 1998; Yusof, 1996). Both ethnic groups were under the Sultans' rule since before the European Powers invaded the Malay States. However, the Malay ethnic was placed on a higher level in term of domination compared to the Orang Asli ethnic. In ancient Malays feudal, the Malays possessed the important levels and posts in the Malays administration feudal system and the Orang Asli mainly been slavery among the Malay highest customs and nobles. Voon (1976) wrote that the disposal of Malay land was the main issue since the 1900s after commercial agricultural activities such as rubber and oil palm planting was introduced by the British Colonial Government in Peninsular Malaysia. Since the commodities were introduced, many plantation companies opened up new lands to cultivate these commodities.

The land for this sector was acquired either through the government alienation land or purchase of land from the Malay owners (Voon, 1976; Mizushima, 1995; Nik Abdul Rashid, 1993; Buang, 2004; Amino \& Suyub, 2008). These studies found transactions of large tracts of land took place and many land settlers as well as the owners sold their land, resulting many of them have to then move to their hometown mainly located in rural areas. It also discovered actions underlying the Malay land owners in Langkawi who tried to revoke the "Malay Reservation" status from their land titles in order to allow the land to be developed as commercial land. The Malay Reserve Land has specified its use for traditional agricultural purposes. However, from eight applications made by the Malay owners, only one application was approved by the State Authority. Talib (1992) identified the factors determining alienation of land by the Malays, namely lucrative prices offered by buyers, conflicts between heirs on estates left by dead relatives and land acquired by the government under the Land Acquisition Act 1960 . These factors were also substantiated by Ridzuan (1994), but he specifically classified these factors into social and political factors. Mamat (1988) identified the factors that contributed to the depletion of Malay land due to the expansion of municipal areas, development of new townships, and the lucrative price offering from the buyer.

Based on the above literature, the depletion of the Malay land ownership can be attributed to the attitude of the Malay land owners who are looking for the better price offered by the buyers. This factor remains since the colonial era until today. The Malays have not found the solution to maintain their rights on the land by the undertaking of the productive economic activities due to lack of enterprise culture. The Malay community were unable to improve their socio-economic standing if their lands are used as capital by selling them to the capitalists or developers who are looking for economic opportunities and benefits from the land after they acquire them from the Malay owners. Therefore, the objective of this study was to identify the impact of development process on the Malay land ownership pattern by analyzing the levels of Malays land loss and reduction.

\section{Research Methodology}

\subsection{Site Description}

This study was undertaken in the three districts, namely the district of Larut, Matang and Selama (LMS); located in the northern part of the State of Perak. LMS is one of the districts which were already developed before the British occupation ever since Long Jaafar was appointed by the Sultan of Perak to administer this area. This district was formerly known as Jajahan Larut where Bukit Gantang was chosen as the capital of the Jajahan. Now, the District of LMS is one of the areas gazetted as part of the area included in the regional corridor development aptly named Northern Corridor Economic Region (NCER) which was launched by the government on $31^{\text {st }}$ July 2007. This area is also unique as it has three main accesses from north to south and one access from east to west i.e. Federal Trunk Road I (Kuala Lumpur-Butterworth), Federal Trunk Road II (Changkat Jering-Gelang Patah), North-South Highway (Kuala Lumpur-Butterworth) and East-West Expressway 
(Batu-Kurau-Lenggong-Grik-Kota Bharu). Table 1 shows the largest population in LMS District is the Malay community which comprises 168,978 peoples or $61.75 \%$ of the total population of 273,641 people, whilst other ethnic groups such as Eurasians, Arabs, Pakistani and Siamese form the smallest population comprising 516 peoples $(0.19 \%)$. In this district context, the non-Malays primarily the Chinese and Indian populations comprised $68,955(25.20 \%)$ and 31,307 (11.44\%) peoples respectively. The main economic activities in LMS district are local agricultural produce such as local fruits, kampong (village) and mixed agricultural activities mainly operated by the rural Malay peasants, commercial agricultural such as oil palm and rubber plantations operated by National Farming Companies and smallholders, as well as other commercial and industrial sectors.

Table 1. Ethnic groups in the district of LMS

\begin{tabular}{lll}
\hline Ethnic Groups & Peoples & (\%) \\
\hline Malays & 168,978 & 61.75 \\
Other Bumiputeras (Native Groups) & 864 & 0.32 \\
Chinese & 68,955 & 25.20 \\
Indians & 31,307 & 11.44 \\
Others & 516 & 0.19 \\
Non-Malaysians & 3,021 & 1.10 \\
Total & $\mathbf{2 7 3 , 6 4 1}$ & $\mathbf{1 0 0 . 0 0}$ \\
\hline
\end{tabular}

Source: Department of Statistics, Malaysia, 2000

\subsection{Data Collection and Analysis}

The researcher used primary data in the form of land transaction acquired from the Department of Valuation and Property Services (Perak State) from year 2000 to 2008. These data were originally registered once the seller and the buyer agreed to execute the transaction and the seller filled all information required in the Form 14A provided under the National Land Code 1965 supplied by the LMS Land Office. These data were in the form of softcopy and were kept in DVPS (Perak State). It is also known as the 'Sale Evidences' among the evaluators who conducted the valuation exercises.

The study used a quantitative method to analyse the land transaction in the study area (Wigginton, 2005). In this analysis, data were classified into two main transaction groups namely transaction between the Malay sellers and the non-Malay buyers and transaction between the non-Malay sellers and the Malay buyers. Specifically, both groups were differentiated into three groups; through the cross-tabulation of the following aspect; between the Mukims and year of transactions, between land area and year of transactions and between types of agriculture used and year of transactions. However, the cross-tabulation of data between the ethnic transaction among the Malays and non-Malays was the major process in order to determine the mode of the variables tested. The final analysis was the comparison analysis between the highest and lowest number of land transaction which provided a basis to determine the level of the Malays' land loses to the non-Malays.

\section{Result and Discussion}

This section comprehends the results of the land transactions mainly the agricultural lands owned by the Malays in three districts - Larut, Matang and Selama. About 3,671 land transactions have been analyzed. These study areas showed most of the agricultural lands were the Malays dominated land in rural areas. Taking a descriptive analysis on four aspects; the trend of Malay ownership on land, land area, types of agricultural and year of transaction, the followings are the results of the study.

\subsection{Agricultural Land Transaction}

Table 2 shows 3,671 land were transacted between year 2000 and 2008 in the study area where the highest transactions were undertaken between the Malays which projected about 1,759 transactions $(47.92 \%)$. These transactions were contributed by the Malay Reserved Lands dealings. This category of land is subjected to the provisions in Malay Reservation Enactment that strictly prohibits the Malays from disposing the Malay Reserved Lands to the non-Malays. The lowest category of transaction is the land transferred from the non-Malays to the Malays; that was six transactions $(0.16 \%)$.

However, the critical issue here was the transaction of land from Malays to non-Malays where during this period, 
the results show that 182 transactions $(4.92 \%)$ with the land area about 217.16 hectares occurred. By comparison, the Malays only acquired about 12.57 hectares of lands (six transactions) from the non-Malay sellers. It is a worrying trend because land owned by the Malays is gradually reduced; and with minimal control the Malays will lose their lands to the non-Malays. This scenario had happened even without any development programs gazetted by the government.

Looking back into the history, most of the Malay community in rural area mainly from the lower income group was inherited in the traditional life style from their past generation. They still practice the norms of the social class similar to their ancestors during the colonialization era. During the British administration, the colonial power imposed and implemented the famous policy known as "Divide and Rule" policy, aiming at segregating the multi-racial ethnic in the British Malaya colony. In this policy, each of the ethnic groups was segregated in terms accordingly to the economic involvement. The Malays were allocated and settled in the rural areas; and they practiced traditional agriculture activities (Abdul Muati, 2010; Muhammad Fauzi, 2010; Firdaus, 1997; Kheng, 1992 and Hagiwara, 1972). This activity remains as an identity of the rural Malay society, also known as the second class citizen in modern Malaysia.

Table 2. Agricultural land transactions between the year 2000 and 2008

\begin{tabular}{lllll}
\hline Category & \multicolumn{1}{l}{ No. of Transactions } & $\mathbf{( \% )}$ & Land Area (Hectare) & $\mathbf{( \% )}$ \\
\hline Malay to Malay & 1,759 & 47.92 & $1,433.09$ & 29.67 \\
Malay to Non-Malay & 182 & 4.96 & 217.16 & 4.50 \\
Non-Malay to Malay & 6 & 0.16 & 12.37 & 0.26 \\
Non-Malay to Non-Malay & 875 & 23.84 & $1,377.33$ & 28.52 \\
Others & 849 & 23.13 & $1,789.57$ & 37.05 \\
Total & $\mathbf{3 , 6 7 1}$ & $\mathbf{1 0 0 . 0 0}$ & $\mathbf{4 , 8 2 9 . 5 2}$ & $\mathbf{1 0 0 . 0 0}$ \\
\hline
\end{tabular}

Source: Modified from the Department of Valuation and Property Services, Malaysia, 2009

\subsection{Transactions of Land by Ethnic Buyer and Seller}

Table 3 shows the transactions of land between the Malays and non-Malays by Mukims (Sub-districts) and Year of Transactions. This analysis demonstrates the transaction between the Malay sellers and Chinese buyers involved a huge land size of 170.24 hectares $(78.39 \%)$ out of 217.16 hectares. The Indian buyers had acquired 43.6417 hectares $(20.10 \%)$ and the Sikh purchasers bought about 3.28 hectares $(1.51 \%)$ from the Malay sellers. On the other hand, land acquisition from the non-Malays by the Malay buyers was 12.37 hectares $(5.70 \%)$. The Chinese recorded the highest of land disposal accounting 8.13 hectares $(65.75 \%)$, followed by the Indians is 4.24 hectares (34.25\%) to the Malay buyers. The Sikhs have not disposed any land to the Malays. 
Table 3. Cross-tabulation of land area transactions between Mukims and year of transactions, 2000-2008

\begin{tabular}{lrrrrrr}
\hline \multicolumn{1}{c}{ Mukims } & \multicolumn{2}{c}{ Chinese } & \multicolumn{2}{c}{ Land Area (hectare) } & \multicolumn{2}{c}{ Indian } \\
& Buyer & Seller & Buyer & Seller & Buyer & Seller \\
\hline Assam Kumbang & 19.44 & - & 2.87 & - & 0.92 & \\
Bandar Matang & 0.36 & - & - & - & - & - \\
Batu Kurau & 13.12 & 1.10 & 6.98 & - & - & - \\
Bukit Gantang & 6.03 & - & 6.27 & 0.16 & - & - \\
Hulu Selama & 0.84 & - & - & 1.30 & - & - \\
Jebong & 7.80 & - & 3.72 & - & - & - \\
Kamunting & 8.75 & 1.41 & - & - & - & - \\
Selama & 11.57 & - & 16.07 & 0.46 & - & - \\
Sg. Limau & 1.37 & - & 0.80 & & - & - \\
Sg. Tinggi & 69.42 & 5.63 & 5.69 & 1.28 & - & - \\
Simpang & 0.14 & - & 1.24 & - & - & - \\
Trong & 6.19 & - & - & - & 2.36 & - \\
Tupai & 25.19 & - & - & 1.05 & - & - \\
Total & $\mathbf{1 7 0 . 2 4}$ & $\mathbf{8 . 1 3}$ & $\mathbf{4 3 . 6 4}$ & $\mathbf{4 . 2 4}$ & $\mathbf{3 . 2 8}$ & $\mathbf{0 . 0 0}$ \\
\hline Source: & &
\end{tabular}

Source: Modified from the Department of Valuation and Property Services, Malaysia, 2009

Table 4 shows the incremental/reduction of Malay land ownership in the study area by using the following formula:-

$\begin{aligned} & \text { Incremental/ } \\ & \text { reduction of Malay } \\ & \text { land ownership }\end{aligned} \quad=\quad \begin{gathered}\text { Land Area (hectare) that } \\ \text { transacted between the Malay } \\ \text { Sellers and Non-Malay Buyers }\end{gathered}$

The analysis shows the Malays land ownership was reduced to 204.79 hectares $(94.30 \%)$. These lands currently owned by the non-Malay owners. Mukim Hulu Selama saw an incremental of land area whilst other Mukims had experienced the reduction of land area at the highest percentage rate.

Table 4. The incremental/reduction analysis between Mukims and year of transactions, 2000-2008

\begin{tabular}{lrrrrr}
\hline \multicolumn{1}{c}{ Mukims } & Malay Sellers & $\begin{array}{r}\text { Land Area (hectare) } \\
\text { Non-Malay Buyers }\end{array}$ & Differences & \multicolumn{1}{c}{ \% } & Indicator \\
\hline Assam Kumbang & 23.23 & 0.00 & -23.23 & -100.00 & Reduced \\
Bandar Matang & 0.36 & 0.00 & -0.359 & -100.00 & Reduced \\
Batu Kurau & 20.10 & 1.10 & -19.00 & -94.55 & Reduced \\
Bukit Gantang & 12.29 & 0.16 & -12.14 & -98.73 & Reduced \\
Hulu Selama & 0.84 & 1.30 & 0.45 & 53.87 & Increased \\
Jebong & 11.53 & 0.00 & -11.53 & -100.00 & Reduced \\
Kamunting & 8.75 & 1.41 & -7.34 & -83.87 & Reduced \\
Selama & 27.65 & 0.46 & -27.19 & -98.33 & Reduced \\
Sg. Limau & 2.18 & 0.00 & -2.18 & -100.00 & Reduced \\
Sg. Tinggi & 75.11 & 6.91 & -68.21 & -90.8 & Reduced \\
Simpang & 1.38 & 0.00 & -1.38 & -100.00 & Reduced \\
Trong & 8.55 & 0.00 & -8.55 & -100.00 & Reduced \\
Tupai & 25.19 & 1.05 & -24.14 & -95.84 & Reduced \\
Total & $\mathbf{2 1 7 . 1 6}$ & $\mathbf{1 2 . 3 7}$ & $\mathbf{- 2 0 4 . 7 9}$ & $\mathbf{- 9 4 . 3 0 \%}$ & Reduced
\end{tabular}

Source: Modified from the Department of Valuation and Property Services, Malaysia, 2009 
Table 5 shows the number of agricultural land transactions by ethnic categories by year of transactions and land area. The analysis confirms that the Chinese had acquired the highest land transaction from the Malays in 2005, totaling 34.98 hectares $(20.52 \%)$. It follows by the Indian purchasers involving the land size of 11.40 hectares (26.11\%) in 2007 and the Sikhs in 2002 accounting 2.36 hectares (72.02\%). The Malays had acquired huge land from the Chinese in 2004 which recorded at 5.63 hectares (69.18\%). Following ARE the Indian sellers; 1.69 hectares $(39.79 \%)$ in year 2007. There has no land acquired from the Sikhs.

Table 5. Land area and year of transactions by ethnic buyers and sellers, 2000-2008

\begin{tabular}{rrrrrrr}
\hline \multirow{2}{*}{ Year } & \multicolumn{2}{c}{ Chinese } & \multicolumn{3}{c}{ Land Area (hectares) } & \multicolumn{2}{c}{ Sikhs } \\
& Buyer & Seller & Buyer & Seller & Buyer & Seller \\
\hline 2000 & 0.80 & - & - & - & - & - \\
2001 & 0.50 & - & - & - & - & - \\
2002 & 16.20 & - & 4.32 & 1.05 & 2.36 & - \\
2003 & 22.45 & 0.57 & 2.32 & 0.07 & - & - \\
2004 & 28.10 & 5.63 & 6.19 & - & 0.92 & - \\
2005 & 34.98 & - & 9.04 & 1.43 & - & - \\
2006 & 31.73 & 1.94 & 4.33 & - & - & - \\
2007 & 21.19 & - & 11.40 & 1.69 & - & - \\
2008 & 14.29 & - & 6.04 & - & - & - \\
Total & $\mathbf{1 7 0 . 2 4}$ & $\mathbf{8 . 1 3}$ & $\mathbf{4 3 . 6 4}$ & $\mathbf{4 . 2 4}$ & $\mathbf{3 . 2 8}$ & $\mathbf{0 . 0 0}$ \\
\hline
\end{tabular}

Source: Modified from the Department of Valuation and Property Services, Malaysia, 2009

Table 6 shows the incremental/reduction of Malay land ownership in term of land area and year of transactions by using the following formula:-

$\begin{array}{ccc}\begin{array}{c}\text { Incremental/ } \\ \text { reduction of Malay } \\ \text { land ownership }\end{array} \quad=\quad \begin{array}{c}\text { Land Area (hectare) that } \\ \text { transacted between the Malay } \\ \text { Sellers and Non-Malay Buyers }\end{array} & \begin{array}{c}\text { Land Area (hectare) that } \\ \text { transacted between the Non- } \\ \text { Malay Sellers and Malay Buyers }\end{array}\end{array}$

The analysis showed no incremental of land area in each year of transactions. A total $94.30 \%$ or 204.79 hectares of the Malay lands were still not fulfilling the land quota that had been disposed to the non-Malays.

Table 6. Incremental/reduction analysis between land area and year of transactions, 2000-2008

\begin{tabular}{crcrrr}
\hline \multirow{2}{*}{ Year of Transaction } & \multicolumn{2}{c}{ Land Area (Hectare) } & & \multirow{2}{*}{ \% } & \multirow{2}{*}{ Indicator } \\
& Malay Sellers & Malay Buyers & Differences & & \\
\hline 2000 & 0.80 & 0.00 & -0.80 & -100.00 & Reduced \\
2001 & 0.50 & 0.00 & -0.50 & -100.00 & Reduced \\
2002 & 22.88 & 1.05 & -21.83 & -95.42 & Reduced \\
2003 & 24.78 & 0.64 & -24.14 & -97.42 & Reduced \\
2004 & 35.21 & 5.63 & -29.59 & -84.02 & Reduced \\
2005 & 44.02 & 1.43 & -42.58 & -96.74 & Reduced \\
2006 & 36.05 & 1.94 & -34.11 & -94.62 & Reduced \\
2007 & 32.59 & 1.69 & -30.90 & -94.82 & Reduced \\
2008 & 20.33 & 0.00 & -20.33 & -100.00 & Reduced \\
Total & $\mathbf{2 1 7 . 1 6}$ & $\mathbf{1 2 . 3 7}$ & $\mathbf{- 2 0 4 . 7 9}$ & $\mathbf{- 9 4 . 3 0}$ & Reduced \\
\hline
\end{tabular}

Source: Modified from the Department of Valuation and Property Services, Malaysia, 2009 
Table 7 shows the number of agricultural land transactions by the non-Malay ethnic categories cross-tabulated by types of agriculture use and year of transactions. The study found that vacant lands were the highest land area disposed by the non-Malays to the Malays; accounting for 66.09 hectares $(30.43 \%)$. Transaction between the Malay sellers and the non-Malay buyers showed that vacant lands were disposed to the Chinese and Indian purchasers with 48.62 hectares $(25.56 \%)$ and 17.46 hectares $(40.01 \%)$ respectively. The Sikh purchasers however, acquired the highest of land categorized "nil" for 2.36 hectares $(72.02 \%)$. Transaction between the non-Malay sellers and the Malay buyers recorded the land categorized as the oil palm plantations; which was the highest transaction of the Chinese sellers of 3.05 hectares (37.49\%). From the Indian sellers, rubber lands showed the highest transaction -1.30 hectares (30.59\%) and no record transaction between the Sikh sellers and the Malay buyers.

Table 7. Agricultural land disposed by the non-Malay ethnics by types of agriculture use and year of transactions, 2000 and 2008

\begin{tabular}{lrccccc}
\hline \multirow{2}{*}{\begin{tabular}{l} 
Types of Agriculture \\
\multicolumn{1}{c}{ Use }
\end{tabular}} & \multicolumn{2}{c}{ Chinese } & \multicolumn{2}{c}{ Land Area (hectare) } & \multicolumn{2}{c}{ Sikhs } \\
& Sellers & Buyers & Sellers & Buyers & Sellers & Buyers \\
\hline Durian & 12.63 & - & - & - & - & - \\
Orchard & 25.30 & 1.94 & 2.10 & - & 0.92 & - \\
Rubber & 19.43 & 2.58 & 1.93 & 1.30 & - & - \\
Kampong & 0.60 & - & - & 0.16 & - & - \\
Coconut & 0.30 & - & - & - & - & - \\
Oilpalm & 22.55 & 3.05 & 13.00 & - & - & - \\
Paddy & 0.24 & - & - & - & - & - \\
Rambutan & - & - & - & 1.28 & - & - \\
Vacant Land & 48.62 & - & 17.47 & 0.39 & - & - \\
Mixed Agriculture & 2.97 & - & 2.51 & - & - & - \\
Nil & 37.59 & 0.57 & 6.64 & 1.12 & 2.36 & - \\
Total & $\mathbf{1 7 0 . 2 4}$ & $\mathbf{8 . 1 3}$ & $\mathbf{4 3 . 6 4}$ & $\mathbf{4 . 2 4}$ & $\mathbf{3 . 2 8}$ & $\mathbf{0 . 0 0}$ \\
\hline Source: Modifian
\end{tabular}

Source: Modified from the Department of Valuation and Property Services, Malaysia, 2009

Table 8 shows the incremental/reduction of Malay land ownership in term of types of agriculture use and land area by using the following formula:-

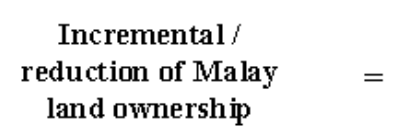

Incremental/ land ownership
Land Area (hectare) that transacted between the Malay Sellers and Non-Malay Buyers
Land Area (hectare) that transacted between the NonMalay Sellers and Malay Buyers 
Table 8. Incremental/reduction analysis between types of agriculture use and year of transactions, 2000-2008

\begin{tabular}{lrrrrr}
\hline \multirow{2}{*}{ Types of Agriculture Use } & \multicolumn{3}{c}{ Land Area (hectare) } & \multirow{2}{*}{ Indicator } \\
\hline Durian & Buyers & Sellers & Differences & & \\
Orchard & 12.63 & 0.00 & -12.63 & -100.00 & Reduced \\
Rubber & 28.32 & 1.94 & -26.38 & -93.16 & Reduced \\
Kampong & 21.36 & 3.87 & -17.48 & -81.86 & Reduced \\
Coconut & 0.60 & 0.16 & -0.44 & -73.96 & Reduced \\
Oilpalm & 0.30 & 0.00 & -0.30 & -100.00 & Reduced \\
Paddy & 35.55 & 3.05 & -32.50 & -91.42 & Reduced \\
Rambutan & 0.24 & 0.00 & -0.24 & -100.00 & Reduced \\
Vacant Land & 0.00 & 1.28 & 1.28 & 100.00 & Increased \\
Mixed Agriculture & 66.09 & 0.39 & -65.70 & -99.41 & Reduced \\
Nil & 5.48 & 0.00 & -5.48 & -100.00 & Reduced \\
Total & 46.59 & 1.69 & -44.91 & -96.38 & Reduced \\
\hline Source: Modifed frod & $\mathbf{2 1 7 . 1 6}$ & $\mathbf{1 2 . 3 7}$ & $\mathbf{- 2 0 4 . 7 9}$ & $\mathbf{- 9 4 . 3 0}$ & Reduced \\
\hline
\end{tabular}

Source: Modified from the Department of Valuation and Property Services, Malaysia, 2009

The above analysis showed that, the Malay land ownership had reduced to 12.37 hectares $(5.70 \%)$ compared to the land were disposed by the non-Malays of 204.79 hectares (94.30\%). Only Rambutan land noted the incremental of land area which is 1.28 hectares and other types of agriculture use recorded the reduction of land area between $81.86 \%$ and $100.00 \%$.

\subsection{Land Transactions between the Malays}

The transaction of agricultural lands amongst the Malays is the highest frequency compared to the other categories of buyers and sellers within the study area. Based on the data analyzed from the year 2000 to 2008 , there were 1,759 units of agricultural lands being transferred between them. This finding is an actual scenario that occurred in this study area and it debunks the perceptions of previous researchers and ordinary people who conducted research on the perception and mentality of the Malays who willingly transfer their land rights to the non-Malays.

The author believes that modern Malays realize the importance of land in order to develop and improve the Malay socio-economic agenda through the exploitation of land for productive use. In other words, the Malays also know that if the land falls to the non-Malays, maybe their future generation will not inherit their ancestors' lands to develop their socio-economic standing. Therefore in order to maintain the continuation of land ownership by the Malay community and to improve their socio-economic standing especially for the rural Malay community, the ancestral lands must remain within the community. This will ensure that the Malays can achieve the same socio-economic level as other rural non-Malay communities who control the agricultural sector.

The highest number of land transaction between the Malays was contributed by the Malay Reserved Lands. This category of lands is restricted by the Malay Reservation Enactment 1933 from allowing the Malays transfer their lands to the non-Malays. However, in some cases, a few of MRLs were transferred to the non-Malays either through a transaction between the Malay sellers and de facto Malay buyers (the Malay buyers who were hired by the non-Malay capitalists to purchase a strategic MRL lands with illegal deals) or the MRL revoked the status with the approval from the State Authority.

The study also found that 217.36 hectares were disposed to the non-Malays and the Malays only acquired 12.37 hectares $(5.70 \%)$ of agricultural land through open transactions. Aggregately, the Malay land ownerships were reduced to 204.79 hectares $(94.70 \%)$. Therefore, average of Malay land reduction is 22.75 hectares annually. Between 2000-2008, only a limited numbers of development projects and programs were implemented in the study area. However, this situation had change dramatically due to the introduction of many development projects and programs during the implementation of NCER's strategies by the Federal and State governments since 2007. Hence, it can be concluded that the reduction of Malay land ownerships would be have been increased through voluntary transactions or compulsory purchases in land transactions. 


\subsection{Development Factors as Key Determinant of Land Transactions}

This study also seeks to uncover whether development factors do influence the land transactions. Table 9 shows the development projects and programs currently implemented in the study area, listed and gazette by Federal, State and local governments. The reduction of Malay land ownerships were contributed by the implementation of physical and non-physical development projects and programs in the district of LMS. These projects and programs required land as a prerequisite of development sources. Of the total 16 development projects and programs, 10 projects and programs were physically required to change land use and status while the remaining six projects and programs were non-physical programs that kept the existing land use.

Table 9. Summary of development projects and programs in the district of LMS

\begin{tabular}{lcl}
\hline \multicolumn{1}{c}{ Development Policies and Programs } & Year & \multicolumn{1}{c}{ Level } \\
\hline Malaysian Plans (Five Year Plans) & $1957-2008$ & Federal \\
Indonesia-Malaysia-Thailand Growth Triangle (IMT-GT) & 1990 & Regional \\
Development Allocation in National Budget & $2000-2008$ & Federal \\
Third National Agricultural Policy (DPN3) 1998-2010 & 1998 & Federal \\
National Physical Plan & 2005 & Federal \\
Development Programs by Perak State Economy Planning Unit & $2000-2008$ & State \\
Pelan Strategik Perak Maju 2015 & 2011 & Regional \\
State Structure Plan & 2005 & State \\
Local Plan of the District of Larut, Matang and Selama & 2005 & Local \\
Northern Corridor Economic Region (NCER) & 2007 & Regional \\
Special Area Plan (RKK) & 2005 & Local \\
Implementation of National Agriculture Policy in study area & 1998 & Regional \\
Implementation of Pelan Strategik Perak Maju 2015 in study area & 2011 & Regional \\
Implementation of economy development projects in study area & 2004 & Regional \\
Land Acquisitions gazzeted & $2000-2008$ & District \\
Implementation of physical works & $2000-2008$ & District \\
\hline
\end{tabular}

Source: Researcher, 2012

\section{Conclusion}

This study found that the status/majority of land ownership in the District of Larut, Matang and Selama was still in Malay hands. This was reflected in the transaction of lands from the year 2000 to 2008 where there were $47.92 \%$ from 3,671 units of agricultural lands transacted amongst the Malays. The main contributor to this phenomenon is the restrictions imposed on the land gazette as Malay Reserve Land. Another reason is the rise of awareness on the importance of land ownership to be kept within the Malay community.

The transactions between the Malays and non-Malays however still happen in the study area. It is because the non-Malay buyers offered better or higher price compared to the Malay buyers. The transaction trend in 2000 till 2008 saw on average 22.75 hectares of land owned by the Malays were transacted to the non-Malays, and only 12.37 hectares or 1.37 hectares were annually returned to the Malays.

On the other hand, the transaction of lands from the Malays to non-Malays was reduced up to 44.02 hectares in the year 2004, resulting a reduction between 20 hectares and 35 hectares in the following years. This scenario was obviously noticeable after the introduction and announcement made by the Malaysian Government for the mega development projects and programs especially in the Northern Corridor Economic Region (NCER); the KTMB Double Tracks from Ipoh to Padang Besar, Pelan Strategik Perak Maju 2015 and the LMS Local Plan (Sime Darby Berhad, 2007). These programs are also formulated to improve the socio-economic level of the rural community whereby the Malays make up the highest population occupying this area and had been involved in the traditional agricultural activities and small scale commercial-agricultural sector for decades. It is anticipated although the Malays land ownership will continuously be reduced when these land are transformed 
into more production economic sector, they are not the marginalized from the mainstream economy of the region and the nation at large.

\section{Acknowledgement}

This research is financially supported by the following research grants, UKM-DPP-2013-083, Dana Pembangunan Penyelidikan Kumpulan; Development and Socio-economical Vulnerabilities, Universiti Kebangsaan Malaysia and UKM-DLP-2012-030 Dana Lonjakan Penyelidikan under the leadership of Associate Prof. Dr. Er Ah Choy.

\section{References}

Abdullah, A. N. (1985). Undang-Undang Tanah Simpanan Melayu. In K. K. Kim (Ed.), Sejarah Masyarakat Melayu Moden. Kuala Lumpur: Jabatan Penerbitan Universiti Malaya.

Abdullah, F. (1997). Affirmative Action Policy in Malaysia : To Restructure Society, to Eradicate Poverty. Ethnic Studies Report.

Ahmad, A. M. (2010). The Dilemma of the Malays : Rhetorical Analysis of Selected Speeches of Tunku Abdul Rahman Putra, The First Prime Minister of Malaysia, 1957-1970. Human Communication, 357-368.

Ahmad, Y. (1996). Perjuangan Yang Belum Selesai. Persidangan Dewan Perniagaan Melayu Malaysia. Kuala Lumpur.

Amino, A., \& Suyub, R. N. (2008). Tanah Rizab Melayu: Kaedah-Kaedah memaju dan mengekalkan pemilikannya. Johor Bahru: Universiti Teknologi Malaysia.

Anderson, J. A. (1999). The politics of land scarcity: Land disputes in Save Communal Area, Zimbabwe. Journal of Southern African Studies, 25(4), 553-578. http://dx.doi.org/10.1080/030570799108470

Asiah Othman, R. A. (2006). Implikasi Pencerobohan Tanah Kerajaan. Kajian Kes: Bandaraya Johor Bahru. Johor Bahru: Laporan Akhir Penyelidikan Jangka Pendek.

Asmuni, M. F. (2010). Menilai kemelut politik tempatan berdasarkan Maqasid Syarak. In Konvensyen Pemikiran Hasan Al-Bana Dalam Melakar Agenda Bangsa (pp. 1-18). Putrajaya: UNITEN.

Awang, R. (1994). Undang-Undang Tanah Islam - Pendekatan Perbandingan. Kuala Lumpur: Dewan Bahasa dan Pustaka.

Buang, A. (2007). Pertanian Melayu dan Kelestariannya. Bangi: Penerbit UKM.

Buang, S. (1989). Malay Customary Tenure - A Brief Historical Survey. In A. Ibrahim, \& J. Sihombing (Eds.), The Centenary of the Torrens System in Malaysia. Kuala Lumpur: Malayan Law Journals Sdn Bhd.

Buang, S. (1993). Undang-Undang Tanah di Malaysia. Kuala Lumpur: Dewan Bahasa dan Pustaka.

Buang, S. (1997). Dimensi baharu masyarakat Malaysia. Masalah Undang-Undang. Kuala Lumpur: Dewan Bahasa dan Pustaka.

Buang, S. (2003). Kanun Tanah Negara 1965 dan Pelbagai Undang-Undang Berkaitan Tanah: Satu Tinjauan. Seminar Land Administration and Legislations for District Officers/Land Administrators in Peninsular Malaysia. Kuala Lumpur.

Buang, S. (2004). Questions over Malay Reserve Lands. Retrieved October 15, 2010, from http://www.hba.org.my/articles/salleh_buang/2004

Buang, S. (2006). Kanun Tanah Negara 1965 dan Pelbagai Undang-Undang Berkaitan Tanah: Satu Tinjauan. Jurnal Institut Tanah dan Ukur Negara .

Buang, S. (2007). Malaysian Torrens System (2nd ed.). Kuala Lumpur: Dewan Bahasa dan Pustaka.

Frankema, E. H. (2006). The colonial roots of Latin American land inequality in a global comparative perspective: Factor endowments or political economy? Center for the Evolution of the Global Economy. Groningen: University of Groningen.

Hadi, T. I. (1996). Langkawi - The Hub of the Indonesia, Malaysia, Thailand Growth Triangle (IMT-GT). Kuala Lumpur: Pelanduk Publications.

Hagiwara, Y. (1972). Political Culture and Communalism in West Malaysia. Journal of Developing Economies, 250-264. 
Harun, I. D. (2006). Pembangunan Tanah-Tanah Rizab Melayu: Satu Tinjauan Permasalahan dan Perundangan. Jurnal Institut Tanah dan Ukur Negara, 49-52.

Husin, W. N. (2012). Cultural Clash between the Malays and Chinese in Malaysia : An Analysis on the Formation and Implementation of National Cultural Policy. In 2012 International Conference on Humanity, History and Society (pp. 1-6). Singapore: IACSIT Press.

Hussain, S. M. (1996). Tanah Rizab Melayu - Suatu Perspektif Undang-Undang. Conference of Development of Malay Reserve Land. Kuala Lumpur.

Ibrahim, Z. (1983). Perspectives towards investigating Malay peasant ideology and the bases of its production in contemporary Malaysia. Journal of Contemporary Asia, 13(2), 198-209. http://dx.doi.org/10.1080/00472338380000131

Kheng, C. B. (2002). Malaysia : The Making of a Nation. Singapore: Institute of Southeast Asia Studies.

Laws of Malaysia. (2007a). The Federal Constitutions. Kuala Lumpur: International Law Book Services.

Laws of Malaysia. (2007b). The Land Acquisition Act 1960. Kuala Lumpur: International Law Book Services.

Laws of Malaysia. (2009). The National Land Code 1965 National Land Code 1965. Kuala Lumpur: International Law Book Services.

Mamat, A. (1988). Tanah Rizab Melayu: Analisis Prospek Pembangunan. Kuala Lumpur: Institut Tadbiran Awam Malaysia and Jabatan Perkhidmatan Awam Malaysia.

Means, G. P. (1972). Special Rights as a Strategy for Development: The Case of Malaysia. Journal of Comparative Politics, 5(1), 29-6. http://dx.doi.org/10.2307/421353

Mukupa, W. (2011). Land Administration to Support Sustainable Development. FIG Working Week 2011. Morocco.

Mizushima, T. (1995). A Historical Study on Land Transaction in a Perak Kampong, Malaysia, Human Ecology in Rural Malaysia. In Y. Komoguchi (Ed.), Institute for Applied Geography. Komazawa University, Tokyo.

Nik Abdul Rashid, N. A. M. (1993). Malay Reservation Land: Concepts, Seminar on Malay Reservation Land: Development Perspective. Bulletin INSPEN, 8(4), 1-10.

Ramaswamy, S. (2000). Malay Reservation Enactments in Peninsular Malaysia. Kuala Lumpur: International Law Book Services.

Shal, V. (2003). Environment, Development and Indigenous People - Belize. Indigenous Rights in the Commonwealth Caribbean and Americas Regional Expert Meeting. Guyana: Amerindian Peoples' Association.

Berhad, S. D. (2007). Rangka Tindakan Sosio-ekonomi Wilayah Ekonomi Koridor Utara. Retrieved February 2, 2008, from http://www.ncer.com.my

Sullivan, P. (1998). Orang Asli and Malays Equity and Native Title in Malaysia. In C. J. Iorus (Ed.), Land conflicts in Southeast Asia. Indigenous Peoples, Environment and International Law. Bangkok: White Lotus Press.

Voon, P. K. (1976). Malay Reservations and Malay Land Ownership in Semenyih and Ulu Semenyih Mukims Selangor. Journal of Modern Asian Studies, 10(4), 509-523. http://dx.doi.org/10.1017/S0026749X00014931

Wigginton, J. E. (2005). PEDSTATS: Descriptive Statistics, Graphics and Quality Assessment for Gene Mapping Data. London: Oxford University Press.

Yusof, N. M. (1996). Pembangunan Tanah Rizab Melayu dari Perspektif Sejarah, Perundangan dan Pembangunan Masa Depan. Conference of Development Land. Kuala Lumpur.

\section{Copyrights}

Copyright for this article is retained by the author(s), with first publication rights granted to the journal.

This is an open-access article distributed under the terms and conditions of the Creative Commons Attribution license (http://creativecommons.org/licenses/by/3.0/). 